University of Nebraska - Lincoln

DigitalCommons@University of Nebraska - Lincoln

Space, Cyber, and Telecommunications Law

Program Faculty Publications

Law, College of

2003

\title{
Towards One Captain on the European Spaceship- Why the EU Should Join ESA
}

Frans G. von der Dunk

University of Nebraska - Lincoln, fvonderdunk2@unl.edu

Follow this and additional works at: https://digitalcommons.unl.edu/spacelaw

Part of the Air and Space Law Commons

von der Dunk, Frans G., "Towards One Captain on the European Spaceship- Why the EU Should Join ESA" (2003). Space, Cyber, and Telecommunications Law Program Faculty Publications. 56.

https://digitalcommons.unl.edu/spacelaw/56

This Article is brought to you for free and open access by the Law, College of at DigitalCommons@University of Nebraska - Lincoln. It has been accepted for inclusion in Space, Cyber, and Telecommunications Law Program Faculty Publications by an authorized administrator of DigitalCommons@University of Nebraska - Lincoln. 


\title{
Towards One Captain on the European Spaceship- Why the EU Should Join ESA
}

\author{
Frans von der Dunk \\ University of Nebraska-Lincoln, Lincoln, Nebraska, USA; email fvonderdunk2@unl.edu \\ Formerly of: International Institute of Air and Space Law, Leiden University, Leiden, Netherlands
}

\begin{abstract}
The current European Convention, aimed at shaping the future of the EU, is considering inclusion of "space" as an area of competence in the EU treaties, in order to strengthen the position of Europe in space. While the Commission in this context has contemplated turning ESA into a "space agency of the EU," a much more fruitful approach would be the other way around: for the EU to become a member of ESA. As argued, this solution would have a few interesting precedents, be relatively easy and quick to implement, and kill a number of birds with one stone.
\end{abstract}

\section{What is the problem?}

The convergence in the area of outer space and space activities of the European Commission-representing the European Union (EU) - and the European Space Agency (ESA) has recently culminated in the joint elaboration of a European Space Policy. ${ }^{1}$ Thus, it may seem that, by combining the general legislative machinery and political clout of the EU with the technical and operational expertise in space matters of ESA, Europe is finally establishing one single coherent space policy and strategy paradigm.

Looking below the surface, however, things may not be so straightforward. The European Space Policy, important as it might be, is still only a step forward in a long process. As experience shows, the delineation of respective competences and tasks between the two centers of "space power" is not always clear-cut. For example, in defining priorities for research and development, and especially for optional programs, ${ }^{2}$ the ESA Director-General and ESA Council will unavoidably enter the area of policy making, which may at first glance seem to be the Commission's domain. Yet the other way around, if the Commission were, for instance, to insist on enforcing its competition regime ${ }^{3}$ in the space sector, it would substantially and comprehensively interfere with the structure of ESA and its space programs, and hence with its raison d'être in the first place.

A fundamental flaw remains, as a consequence of the fact that the hierarchy of the respective roles of ESA and the EU in terms of space activities has not been established. In each case where the interests of the two do not coincide and thus do not lead to self-evident cooperation, these interests will continue to give rise to institutional tugs-of-war. In short, there are still two captains on the European spaceship today.

And indeed, on a number of occasions, the two institutions seem to be co-operating in a rather circumspect and complicated manner, which tastes more like competition than like co-operation. A case in point is the ambitious Galileo project, which may to a large extent determine the strength of Europe's presence in space for the coming decades. In its desire to get Galileo off the ground by making maximum use of the EU legislative machinery, the Commission sometimes seems to be oblivious of the strengths and experience ESA has

1 Council Resolution on a European Space Strategy, adopted November 16, 2000 (EC and ESA/C-M/CXL VIII/Resolution 1 (Final).

2 Cf. esp. Article V(1.a) and (1.b), Convention for the Establishment of a European Space Agency (hereafter ESA Convention), Paris, done May 30, 1975, entered into force October 30, 1980; 14 ILM 864 (1975).

3 Cf. esp. Article 81, 82, 86 and 87 (ex-Article 85, 86, 90 and 92), EC Treaty (i.e. Treaty establishing the European Economic Community, Rome, done March 25, 1957, entered into force January 1, 1958; 298 UNTS 11; as most recently amended by Treaty of Amsterdam Amending the Treaty on European Union, the Treaties Establishing the European Communities and Certain Related Acts, done October 2, 1997, entered into force May 1, 1999; CONF 4005/97, of September 23, 1997). 
to contribute. From its side, ESA has not always been very forthcoming with its own input when it came to supporting the various projects developing the future contours of Galileo in more detail, paid for by the Commission.

These almost inherent struggles will become a real problem once they start to interfere with the Galileo Joint Undertaking (JU) to be established. ${ }^{4}$ The JU, as a child of ESA and EU charged to lead Galileo through the deployment phase into the operational phase due by 2008, should not suffer from a lack of competence because its parents do not fully trust each other, and are thus hesitant to delegate any real competence to the JU.

It should be remembered, however, that these intrainstitutional issues are fundamentally the result of interplay between sovereign states, through the various constituent treaty members either of the EU or of ESA or of both..$^{5}$ This also means that in the last resort it is up to these member states to ensure that the various conflicts of interests and competences which have arisen (and will probably continue to arise even within the framework of a common European Space Policy) will be minimized or even eliminated.

\section{Where to look for solutions?}

At a recent workshop on European Space Policy in Leuven, ${ }^{6}$ Mr. Jean-Luc Dehaene, Vice-President of the European Convention currently trying to define the future institutional "Euro(land)scape," focused on the option of including explicit references to outer space and space matters in the future Constitutional Treaty, as a means of establishing EU competence (whether exclusive, shared or complementary) in that area.

A possible, and perhaps seemingly logical result of such an inclusion would be for ESA to become the "space agency of the EU," in roughly the same manner as the Western European Union (WEU) is being turned into a "defense agency" of the EU. And indeed, it is well known that for some years Commission officials have more or less officially been contemplating such an approach in the opinion that it might solve any inconsistencies or internal conflicts in defining future European space strategy and policy, and thus make Europe so much the stronger in the global space arena.

Tempting as this idea might look, especially from a
Commission perspective (it requires little imagination to understand that at ESA one is considerably less enthusiastic, let alone in Norway and Switzerland), this is not the solution. The European Union has little experience of actually running an operational organization, and the Commission seems to lack sheer capacity in terms of numbers of staff as well.

ESA undertakes high-technology research and development, develops the results into operational space systems and-as long as pre-commercial-even operates these systems; it has built up unique experience in doing so over the decades of its existence. Any subordination of the well-weathered machinery of ESA to the preciously small number of Commission officials who would actually control those activities simply would not work, and would probably spell the end of the European R\&D and presence in space as we currently know it.

These problems are exacerbated by the impending enlargement of the EU, which will not only stretch the Commission's capabilities to the extreme, but will also result in a number of states having a say, through the EU-legislative machinery, over expensive and still nonroutine activities in which they have, so far, nothing at stake politically as well as financially.

The European Union and its predecessor(s), the European Community/ies, were developed to pool together the legislative resources wherever it was considered-as an overarching policy imperative-that the greater common good of the European members would be served thereby. That is where its strength lies, and where all its political clout has developed. Sometimes, and increasingly so as a result of the ongoing commercialization of space activities, the competences developed on the basis of this legislative pooling do touch upon issues of space, but this is still marginal in view of the overall thrust of EU policy and legislation.

By contrast, ESA has been established for purposes of pooling, wherever considered beneficial, the financial resources and know-how of its member states exclusively for space research, development and activities - apparently these were considered important policy imperatives at the time. In view, for example, of the (over)enthusiastic financial subscription of ESA member states to the optional program Galileo, ${ }^{7}$ it can safely be concluded that these policy imperatives still hold true.

\footnotetext{
4 Council Regulation (EC) No. 876/2002 of May 21, 2002 setting up the Galileo Joint Undertaking; OJ L 138, of May 28, 2002, pp. 1-8.

5 It is often neglected, that whilst currently 13 states are member states of both EU and ESA, ESA members Norway and Switzerland are not members of the EU, whereas EU members Luxembourg and Greece are not members of ESA. This issue may actually become exacerbated with the future accession to the EU of some ten Middle and Eastern European states, none of which are ESA members as of yet.

6 Second European Space Policy Workshop, "The Stakeholders and their Interests," organized by the Katholieke Universiteit Leuven and Systemics Network International on January 10, 2003 in Leuven, Belgium.

7 Originally, ESA's Galileo optional program, constituting the ESA share complementary to the share of the total budget allocated through the EU Council and the relevant EU programs, was oversubscribed by some $33 \%$. At the time of writing, a deadlock still exists between Germany and Italy over the industrial leadership of the program as neither wants to diminish its proposed $25 \%$ share of the program.
} 


\section{Why this solution?}

Thus, it would be appropriate to look for other alternatives, as the underlying problem remains unsolved. In this respect, the option of the EU becoming a member of ESA jumps to the eye as the most efficient and rapidly achievable solution, and should be seriously studied as to its further ramifications, possibilities and challenges. Although it may seem a rather strange construction to have one international body (even if not a classical intergovernmental organization anymore, but endowed with a number of quasi-federal characteristics) becoming member of another as if it were a state proper, of course this nevertheless does not constitute a complete novelty.

In particular, the case of Eurocontrol, the European organization for aviation safety, is relevant, since here also the Commission for a considerable time entertained the idea to try and integrate Eurocontrol into the EU structure, as an operating agency of the Commission. In the end, however, the other way round as it were, it was the EU which became a member of Eurocontrol. Other precedents, or analogous cases, also offer themselves for further scrutiny, such as EU membership of the World Trade Organization (WTO).

Of course, a number of major legal and institutional issues would remain to be dealt with. One of them concerns the voting procedures, especially in the light of the co-existence within the EU legal and institutional framework of exclusive competences of the EU and shared or complementary competences, where the member states still have room for autonomously and individually injecting their own national policy interests into the law-making process in the EU. Should the EU have 15 votes in the case of a vote on a subject where exclusive competence applies, or just one? Should it have an additional vote in case of shared or complimentary competences, or should the Commission somehow simply internally co-ordinate within the applicable EU rules, with the member states still voting each on their own account?

Happily, the hallmark of the ESA legal framework is flexibility. Thus, while ESA currently counts 15 member states, in addition it has a long-standing and almost institutionalized co-operation agreement with Canada as a "Co-operating State," whereas it also has the instrument of an Associate Membership status readily available. There should be little doubt that, especially if recourse is being had to the precedents cited, an ap- propriate legal instrument could be relatively easily and rapidly created for optimizing, legally speaking, any adherence of the EU to the ESA Convention.

The flexibility inherent in the ESA framework is also pre-eminent in the area of space programs itself. The existence of ESA does not preclude member states from operating their own space programs, if they so desire; it rather presents a platform-and as such already a stimulus - for looking at possibilities for enhancing efficiency and the chances of success at a European level. Once programs are proposed within the ESA framework, the instrument of optional programs allows for an optimum combination of the interests of states on the one hand in maintaining their discretion in joining certain programs - in other words, in implementing their national policy priorities - and on the other hand, in promoting European co-operation in space.

For these programs, the voting procedure is not the essence (votes on adoption of a certain program follow the "classical" procedure of "one state, one vote majority voting"); the essence is how much those states desiring to participate in that program wish to contribute. In contributing more, a state naturally gains more influence over the way the program will actually be run.

\section{How would it work?}

In many ways, EU membership of ESA, to be taken care of by the Commission, would result in a logical and transparent construction, which could moreover be easily and relatively rapidly realized. No difficult process of legal and institutional integration into the enormously detailed EU legal and institutional structure, taking care of all relevant aspects of the acquis communautaire, would be needed; a single protocol or other special document of accession after a thorough yet wellconfined study of the legal ramifications and special aspects should suffice.

In this fashion, any EU policy interest would already be given shape through its contribution in the framework of ESA to the discussions and, more to the point, to the relevant programs. If the EU's strong interest in a particular proposed project were not taken on board in the ESA framework, there would always be the possibility for the Commission to develop a project outside the ESA framework (as it has at some point contemplated in the past ${ }^{8}$ ), or even to develop a project together with individual member states. ${ }^{9}$

8 In 1991, plans were put forward by the Commission to fund "Green Eye in the Sky," a distinct earth observation satellite for environmental purposes; these plans were toned down by January 1994 to the decision to fund a remote-sensing instrument on board the SPOT-4 satellite.

9 The best-known example of an international European space program outside the ESA framework concerns the SPOT remote-sensing satellite system, a French initiative for which the French government managed to interest Sweden and Belgium, and at a later stage also Italy, to the extent of joining at a minority share level. 
The background to ESA's industrial policy, as given shape in particular through optional programs, also offers interesting further options for the EU and the Commission to develop policy priorities. The result of any investment by an individual member state in an optional program is, essentially, that the (private) space industry of that state is being offered an excellent opportunity to be awarded relevant ESA contracts under that program through the "fair return" principle. $^{10}$

Transposing this mechanism to a situation where, under any of its programs, whatever its focus and legal basis (examples such as agriculture, environment and transport-Galileo!-come to mind), the EU can invest in an optional program, the EU would even be able to kill three birds with one stone. By choosing companies to fulfill its "entitlement" under "fair return," it could give preference to companies established in a truly EUoriented fashion, thus for example breathing new life into the concept of a "European Company." It could, in addition, generate more competition for the current ESA mode of contracting industry in the context of optional programs. ${ }^{11}$ Any company from an EU member state would in principle be eligible to qualify for the EU's "entitlement," and might certainly wish to compete for it if it did not succeed in becoming part of the "entitlement" of its own state proper (if such state had cared to invest in such program in the first place). And finally, the EU could further other more general economic policy objectives, such as stimulating SMEs or start-up companies, precisely by distributing its "entitlement" under the "fair return" principle to some categories rather than others.

Also, EU membership of ESA would take account of the continuing process taking place within the European Union. In the name of the "ever closer union"12 of the nations and people involved, areas and issues subject to shared or complementary competences are then brought within the remit of the EU's exclusive competences. With both the EU and the member states present in ESA, and purportedly both scenarios having been allowed for and properly dealt with, such an internal EU evolution could be accommodated by ESA in a very flexible manner.

In short, the underlying hierarchy issue would be solved in a most convenient, transparent and logical manner. The European Space Agency would be the sole captain on the European spaceship, as it has been for a number of years to the general benefit of the European space industry and the economies and societies involved. The European Union would, as it were, accede to the board of the shipping company, ultimately controlling the captain and his ship. Whether this requires a change in EU treaty law, and in particular whether it requires inclusion of space in the area of competence of the EU under the Constitutional Treaty to be drafted, is therefore in a sense a secondary question; but for the beneficial progress of Europe's journey in space, the above solution seems the most adequate, certainly in the short run.

10 See Article IV, Annex V, ESA Convention.

11 It may be noted that, indeed, the "fair return" principle has drawn repeated criticism from EU circles because of its potential anti-competitive effects. So far, the overriding interest also of the EU in a strong and healthy European space industry has precluded the relevant EU bodies from taking any action, but the unease remains in principle.

12 Article 1 (ex-Article A), Treaty on European Union, Maastricht, done February 7, 1992, entered into force November 1, $1993 ; 31$ ILM 247 (1992); as most recently amended by Treaty of Amsterdam Amending the Treaty on European Union, the Treaties Establishing the European Communities and Certain Related Acts, done October 2, 1997, entered into force May 1, 1999; CONF 4005/97, of September 23, 1997. 